\title{
Psychiatric Symptoms in
} Women with Polycystic

\section{Ovary Syndrome}

\section{Hatice Harmanci', Sabri Herguner ${ }^{2}$, Harun Toy ${ }^{3}$}

'Psychiatry Resident, Gaziosmanpasa University, Faculty of Medicine, Department of Pscyhiatry, Tokat - Turkey

${ }^{2}$ Assist. Prof. Dr., Necmettin Erbakan University,

Meram Faculty of Medicine, Department of Child and Adolescent Psychiatry, Konya - Turkey

${ }^{3}$ Assoc. Prof. Dr., Necmettin Erbakan University, Meram Faculty of Medicine, Department of Obstetrics and Gynecology, Konya - Turkey

\section{ABSTRACT}

Psychiatric symptoms in women with polycystic ovary syndrome

Objective: Most of the articles in the literature state that polycystic ovary syndrome (PCOS) is mostly accompanied by psychiatric diseases, and especially, depression and anxiety disorder are seen more frequently in cases of PCOS. With the increase in the level of testosterone in PCOS, many symptoms, such as hirsutism, menstrual irregularity, acne formation, infertility, and obesity appear. These complaints mostly cause negative affect, and the risk for psychiatric symptoms increases. In this study, we compared the level of psychiatric symptoms in women diagnosed with PCOS and healthy women, and investigated its relationship with gender orientation.

Methods: The study included 42 PCOS patients from Meram Medical School, and a group of 42 healthy women, without menstrual irregularity, acne formation and hirsutism who volunteered to participate in the study.

Both groups were similar according to sociodemographic features. Both groups were administered a sociodemographic form prepared by the researchers as well as the Short Symptom Inventory and Bem Sex Role Inventory.

Results: Depression, anxiety disorder, somatization, increased susceptibility in interpersonal relations, obsessive compulsive disorder, phobic anxiety, paranoid thoughts were more frequent in the PCOS group. On the other hand, the level of hostility and psychotic symptoms were similar in both groups.

Conclusion: Psychiatric symptoms were more frequent in the PCOS group, which is consistent with the literature. It is expected that the life quality of PCOS patients will change positively if they are investigated more carefully in the obstetrics and gynecology outpatient clinics and directed to psychiatry outpatient clinics.

Key words: Polycystic ovary syndrome, androgen, psychiatric symptoms

\section{ÖZET}

Polikistik over sendromu olan kadınlarda psikiyatrik belirtiler

Amaç: Yayınların çoğunda polikistik over sendromuna (PKOS) psikiyatrik hastalıkların eşlik ettiği, özellikle depresyon ve kaygı bozukluklarının daha yüksek düzeyde görüldüğü bildirilmiştir. PKOS'da artan testosteron miktarı sebebiyle kıllanmada artış, adet düzensizlikleri, sivilcelenme, kısırlık, obezite gibi semptomlar görülmektedir. Bu şikayetler, çoğunlukla olumsuz duygulanıma sebep olurlar. Bunlarla birlikte, psikiyatrik belirtilerin görülme riski artar. Biz, çalışmamızda PKOS tanısı alan hastalarda, diğer kadınlara oranla psikiyatrik belirtilerin görülme düzeyini ve bunun cinsiyet yönelimiyle ilişkisini araştırdık.

Yöntem: Çalışmaya, Meram Tıp Fakültesi Hastanesi Kadın Doğum Hastalıkları Polikliniği'ne gelen 42 PKOS tanısı almış hasta ve kıyaslama yapabilmek için, 42 sağlıkı veya adet düzensizliği, sivilcelenme veya kıllanma artışı olmayan gönüllü kadın alındı. Kontrol grubu ve çalışma grubunun sosyodemografik özellikleri birbirine benzemekteydi. Her iki gruba da araştırmacıların hazırladığı sosyodemografik form, Kısa Semptom Envanteri ve Bem Cinsiyet Rolü Envanteri uygulandı.

Bulgular: PKOS tanilı hastalarda, kontrol grubuna kıyasla depresyon, kaygı bozukluğu, somatizasyon, kişilerarası ilişkilerde duyarllık artışı, obsesif kompulsif bozukluk, fobik anksiyete, paranoid düşünce düzeyi daha yüksek bulunurken, hostilite ve psikotik bulguların düzeyleri arasında fark bulunamamıştır. Psikiyatrik belirtilerin görülmesinde cinsiyet yöneliminin etkisi olmadığı görülmüştür.

Sonuç: PKOS tanilı hasta grubunda, literatür bilgilerini destekler biçimde, kontrol grubuna göre daha fazla düzeyde psikiyatrik belirtiler görülmektedir. Kadın hastalıkları ve doğum polikliniklerinde bu hastaların daha dikkatli incelenerek psikiyatri polikliniklerine yönlendirilmeleri hastaların yaşam kalitelerini olumlu yönde etkileyecektir.

Anahtar kelimeler: Polikistik over sendromu, androjen, psikiyatrik belirtiler

Address reprint requests to / Yazışma adresi: Psychiatry Resident Hatice Harmanci Gaziosmanpasa University, Faculty of Medicine, Department of Psychiatry, Tokat - Turkey

Phone / Telefon: +90-356-212-9500/3014/1200

E-mail address / Elektronik posta adresi: hatice_harmanci@hotmail.com

Date of receipt / Geliş tarihi: July 3, 2012 / 3 Temmuz 2012

Date of acceptance / Kabul tarihi: August 28, 2012 / 28 Ağustos 2012 


\section{INTRODUCTION}

Polycystic ovary syndrome (PCOS) is the most L common (5-15\%) endocrinological disorder among young women $(1,2)$. Principal complaints include irregular menstruation, acne and hirsutism. Obesity, hair loss, and infertility are among other symptoms (3). Androgen, estrogen and luteinising hormone (LH) levels are increased. Etiology of the disorder is not exactly clear. Also, some drugs like valproic acid, which effects pituitary gland functioning may cause PCOS (4).

Psychiatric symptoms are common in women with PCOS (5). Most common psychiatric disorders are depression and anxiety disorders. Several studies have shown that gynecological, endocrinological and metabolic disorders are directly related with psychiatric disorders (6). PCOS is a chronic disorder and having a chronic disorder is a risk factor for depression (7). Besides depression, anxiety disorders, somatization, aggression and eating disorders are more common in women with PCOS when compared with healthy women $(5,8)$.

In the literature, most of the studies have screened mental disorders such as major depression and anxiety in women with PCOS. Fewer studies investigated frequency of psychiatric symptoms. In this study our aim was to contribute to the existing limited studies on frequency of psychiatric symptoms and review the literature in light of these findings. In our study, as a difference, we also investigated sexual orientation, which is supposed to be affected by increased testosterone levels, and the relationship between sexual orientation and psychiatric symptoms.

\section{METHOD}

\section{Sample}

The sample included 42 female patients who were diagnosed with PCOS at Necmettin ErbakanUniversity Meram Medical School, Department of Obstetrics and Gynecology between July-October 2011. Inclusion criteria were; 1) Being 18-35 years of age, 2) Having at least primary school education, 3) Being diagnosed with PCOS in the last month, 4) Not being on an hormonal treatment for any reason for at least six months, 5) Not having a psychiatric diagnosis and using psychiatric treatment and 6) Not having a chronic medical disease.

PCOS diagnosis was made by residents working in the gynecology outpatient clinic per Rotterdam criteria. According to Rotterdam criteria, PCOS diagnosis is made when two of the following conditions are met: presence of polycystic ovaries, oligoovulation and/or anovulation, excess androgen activity not associated with other pathology (9). Hormonal status was evaluated by drawing blood during the second day of menstruation. In addition, height, weight, waist and hip sizes were obtained to measure body mass index and waist hip ratio. All patients were evaluated with ultrasonograpyhy, gynecological examination and blood tests. After PCOS diagnosis, the aim of the study was explained to the patients by a psychiatry resident and informed consent is obtained. Two patients did not accept to participate in the study and 1 patient was excluded for being on psychiatric treatment. 42 patients who accepted to participate in the study filled sociodemographical data form, Brief Symptom Inventory (BSI) and Bem Sex Role Inventory (BSRI). Control group was selected from healthy women who applied to gynecology and obstetrics outpatient unit for control and who were similar to the patient group in terms of age and othersociodemographical features. Inclusion criteria were also sought in the control group. Institutional review board approval was obtained from Meram Medical School Ethics Board.

\section{Instruments}

1. Data Form: Developed by the researchers by examining the related literature. Form included questions about age, education, marital status, having children, and employment status.

2. Brief Symptom Inventory (BSI): BSI is selfrating scale developed by Derogatis in 1992 (10) and Derogatis and Lazarus in 1994 (11) in order to screen 
various psychological symptoms. BSI is a 53 -item Likert type scale to screen mental symptoms of the individual in the last week. Items are scored from 0 to 4 . BSI consists of ten subscales including somatization, obsessive compulsive disorder, interpersonal sensitivity, depression, anxiety, hostility, phobic anxiety, paranoid ideas, psychoticism and other mental symptoms (12). Validity and reliability of the Turkish form was studied by Şahin and Durak (12).

3. Bem Sex Role Inventory (BSRI): BCRI includes sixty adjectives. Twenty of these adjectives are masculine, twenty are feminine and twenty are about both sexes. In each twenty items, 10 items reflect positive and 10 items reflect negative personality features (social admiration). Each adjective is rated from 1 to 7 (1: never true for me, 7: always true for me). Masculinity, femininity and social admiration scores are calculated separately and divided to three. In this study, we used 40 adjectives excluding social admiration adjectives. Bem (13) developed the scale in 1974, translated to Turkish first by Kavuncu (14) in 1987. Later, Dökmen (15) re-evaluated reliability and validity of the scale.

\section{Statistical Analysis}

Data are analyzed with SPSS (Statistical Package for Social Sciences) 16.0 program. Numerical values are given as mean and Standard deviation. T-test is used to compare continuous variables of the two groups. Association of psychiatric symptoms with various variables were computed with Spearman correlation analysis. Statistical significance is defined as $p<0.05$.

\section{RESULTS}

Fourty two subjects with PCOS and 42 healthy controls were included in the study. There were no differences regarding age, years of education and BMI between the groups (Table 1).

When the BSI results are investigated, PCOS group had significantly higher total BSI score $(p=0.014)$, somatization ( $p<0.001)$, obsessive compulsive disorder $(p=0.007)$, interpersonal sensitivity $(p=0.014)$, depression ( $p=0.007)$, anxiety $(p=0.011)$, phobic anxiety $(p=0.022)$, paranoid ideation $(p=0.047)$ and other psychiatric symptoms $(\mathrm{p}=0.013)$ scores when compared with the control group. Hostility $(p=0.136)$ and

Table 1: Sociodemographic features of the study and control groups

\begin{tabular}{lccc} 
& Study Group (n=42) & Control Group (n=42) & t \\
\hline Age (years) & $22.5 \pm 3.6$ & $22.9 \pm 3.7$ & 0.574 \\
Education (years) & $13.3 \pm 3.0$ & $12.7 \pm 2.4$ & 0.675 \\
BMI & $22.8 \pm 5.5$ & $22.5 \pm 3.7$ & 0.910 \\
WHR & $1.40 \pm 0.11$ & $1.36 \pm 0.17$ & 0.900 \\
\hline
\end{tabular}

BMI: Body mass index, WHR: waist hip ratio, t: Student T test

Table 2: Comparison of BSI scores of the study and control groups

\begin{tabular}{|c|c|c|c|c|}
\hline BSI Subscales & Study Group $(n=42)$ & Control Group $(n=42)$ & $\mathbf{t}$ & $\mathbf{p}$ \\
\hline Total & $68.6 \pm 44.9$ & $43.9 \pm 30.1$ & 2.541 & 0.004 \\
\hline Somatization & $8.5 \pm 6.8$ & $3.9 \pm 4.1$ & 3.426 & $<0.001$ \\
\hline Obsessive compulsive disorder & $9.2 \pm 5.7$ & $6.1 \pm 4.2$ & 2.364 & 0.007 \\
\hline Interpersonal sensitivity & $6.0 \pm 4.2$ & $4.1 \pm 2.9$ & 2.122 & 0.014 \\
\hline Depression & $8.4 \pm 5.9$ & $5.1 \pm 4.8$ & 2.419 & 0.007 \\
\hline Anxiety & $7.6 \pm 6.2$ & $4.6 \pm 4.4$ & 2.502 & 0.011 \\
\hline Phobic anxiety & $4.4 \pm 3.9$ & $2.7 \pm 2.6$ & 1.706 & 0.022 \\
\hline Hostility & $5.9 \pm 4.6$ & $4.4 \pm 4.2$ & 1.000 & 0.136 \\
\hline Psychoticism & $5.7 \pm 4.3$ & $4.2 \pm 3.3$ & 1.676 & 0.083 \\
\hline Paranoid ideas & $7.2 \pm 4.8$ & $5.3 \pm 3.9$ & 1.691 & 0.047 \\
\hline Additional items & $5.6 \pm 4.4$ & $3.5 \pm 3.2$ & 0.040 & 0.013 \\
\hline
\end{tabular}

BSI: Brief Symptom Inventory, t: Student $T$ test 
Table 3: Correlation of various variables with psychiatric symptoms

\begin{tabular}{|c|c|c|c|c|c|}
\hline & BMI & WHR & BSRI-M & BSRI-F & Age \\
\hline Total & 0.212 & 0.078 & -0.089 & 0.041 & 0.043 \\
\hline Somatization & 0.187 & 0.098 & -0.004 & -0.081 & 0.127 \\
\hline Obsessive compulsive disorder & 0.187 & 0.019 & -0.121 & 0.071 & 0.031 \\
\hline Interpersonal sensitivity & 0.173 & 0.121 & -0.053 & 0.128 & -0.049 \\
\hline Depression & $0.223^{*}$ & 0.058 & -0.140 & -0.032 & 0.122 \\
\hline Anxiety & 0.192 & 0.036 & -0.105 & 0.088 & -0.105 \\
\hline Phobic anxiety & 0.162 & 0.126 & -0.009 & 0.137 & -0.022 \\
\hline Hostility & $0.322^{* *}$ & -0.002 & 0.019 & -0.108 & -0.023 \\
\hline Psychoticism & 0.181 & 0.140 & -0.025 & 0.006 & 0.057 \\
\hline Paranoid ideas & 0.186 & 0.062 & -0.097 & -0.021 & 0.046 \\
\hline Additional items & 0.024 & 0.058 & -0.150 & 0.057 & 0.041 \\
\hline
\end{tabular}

BMI: Body mass index, WHR: waist hip ratio, BSRI-M: Bem Sex Role Inventory-Masculinity, BSRI-F: Bem Sex Role Inventory-Femininity ${ }^{*} \mathrm{p}<0.05 ;{ }^{* *} \mathrm{p}<0.01$

psychoticism ( $\mathrm{p}=0.083)$ scores were not significantly different between the groups (Table 2).

Bem Sex Role Inventory femininity (5.9 $\pm 0.6 ; 6.0 \pm 0.5$; $\mathrm{p}=0.714)$ and masculinity $(4.9 \pm 0.8 ; 5.2 \pm 0.7 ; \mathrm{p}=0.136)$ scores were not significantly different between the groups. However, depression $(r=0.223 ; p=0.049)$ and hostility $(r=0.322 ; p=0.002)$ was significantly associated with BMI in the study group. Depression and hostility increased significantly with increasing BMI (Table 3).

\section{DISCUSSION}

In our study, while women with PCOS had higher levels of depression, anxiety, somatization, phobic anxiety, increased sensitivity to interpersonal relations, paranoid ideas and obsessive compulsive symptoms, hostility and psychotic symptoms were not significantly different between the groups. Most of the studies in the literature indicate that the most common mental symptoms accompanying PCOS are depression and anxiety (16) and the most common psychiatric diagnoses are depression and anxiety disorders (1719). In our study we found higher level of depressive symptoms in the study group when compared with the control group. The rates of depression in patients with PCOS in former studies are between 28-64\% (7). Depressive affect is more common in the clinical practice than major depressive disorder. Hirsutism, obesity, irregular menstruation, continuous medical follow up and increased risk of metabolic disorders due to increased insulin resistance are among the factors that have a negative impact on affect of the patients (7).

Obesity is seen in 40-60\% of the PCOS patients (2). Although some studies have suggested that the most important cause of depression in patients with PCOS is increased body mass index along with negative perception of the body (17), there are other studies that did not support this. In a study conducted by Benson et al.(20) in 2008 it was showed that there was no association between depression and obesity in patients with PCOS. Individuals with obesity are more liable to depression from childhood (21); due to low self-esteem (22), negative body image and being subject to negative comments (23). While most of the studies reported higher BMI in patients with PCOS, we did not find any difference in terms of BMI and waist to hip ratio between study and control groups. Hirsutism is seen in $60-90 \%$ of patients and acne is seen in $25 \%$ of the patients with PCOS (24) and these are factors that negatively affect appearance of the individual and lead to negative feelings. Increased testosterone levels lead to hirsutism and acne. In addition, increased testosterone levels are associated with depressive symptoms (25). High androgen level may cause depressive mood, irritability and aggression in women $(26,27)$.

Literature shows that anxiety disorders are more common in patients with PCOS (34-57\%) when compared with healthy women $(7,28)$. According to some studies, anxiety disorders are more common than 
depression (18). Masculine body features due to increased androgen, awareness of possible chronic disorders and problems about reproduction lead to increased anxiety. Acne, which is reported to be a risk factor for anxiety (29), and hirsutism may cause negative affect. Similar to our results, anxiety symptoms are reported higher in the literature. In a meta-analysis by Dokras et al. (16), social phobia, specific phobia, panic disorder and depression are found to be more common in patients with PCOS. Likewise, in our study, we found increased phobic disorder and obsessive compulsive symptoms when compared with the control group. In 2010, Jedel et al.(30) reported increased phobia in patients with PCOS in a study which compared 30 PCOS patients and 30 healthy controls. It has been found that PCOS diagnosis is a risk factor for social phobia (31).

Somatization is defined as expressing things which can not be expressed emotionally by projecting to body (32). In our study, somatization was higher in the patient group. This can be interpreted as a reflection of increased emotional stress in the patients. Similarly, patients had higher sensitivity to interpersonal relations, which is known to be associated with increased sensitivity. Reproductive hormones influence the mood. While increased estrogen has antidepressant effects on women (33), increased androgen levels may lead to antisocial behaviors, incredulity, impulsive behaviors and aggression (26). Consistent with these studies, our results indicated that PCOS patients had higher paranoid ideation when

\section{REFERENCES}

1. Adalı E, Yıldızhan R, Kurdoğlu M, Kolusarı A, Edirne T, Şahin HG, Yildızhan B, Kamac1 M. The relationship between clinicobiochemical characteristics and psychiatric distress in young women with polycystic ovary syndrome. J Int Med Res 2008; 36:1188-1196.

2. Pişkinpaşa S, Yıldız BO. Polikistik over sendromu. Hacettepe Tıp Dergisi 2005; 36:168-174 (Article in Turkish).

3. Niet JE, Koning CM, Pastoor H, Duivenvoorden HJ, Valkenburg O, Ramakers MJ, Passchier J, Klerk C, Laven JSE. Psychological well-being and sexarche in women with polycystic ovary syndrome. Hum Reprod 2010; 25:1497-1503. compared with control group.

While there are studies reporting increased aggression and hostility scores in patients with PCOS (5), we did not find any difference between the patient and control groups in terms of hostility scores. Similarly psychoticism scores were not significantly different. There are other studies which reported that eating disorders are more common and risk of suicide is higher in patients with PCOS (31).

Increased testosterone levels may lead to feeling more masculine along with masculine body features $(34,35)$. In our study, we did not find any difference in BSRI scores and any association between BSRI scores and psychiatric symptoms.

In our study, we found results supporting the limited number of studies which screened psychiatric symptoms in patients with PCOS. An important difference of our study was that we investigated the association of sexual orientation with psychiatric symptoms for the first time. However, usage of self-rating scales to collect the data and the small sample size are the limitations of our study.

\section{CONCLUSION}

Psychiatric symptoms are quite common in patients with PCOS and this impairs quality of life of the individuals. Patients with PCOS must be evaluated more extensively in obstetrics and gynecology outpatient units and eligible patients must be referred to psychiatry clinics.

4. Okay İT, Kisa C, Dilbaz N. Psikiyatrik bozukluklarda valproat kullanımı. Klinik Psikiyatri 2002; 5:33-41 (Article in Turkish).

5. Özenli Y, Haydardereoğlu B, Micozkadıŏ̆lu İ, Şimşek E, Kılıçdağ EB, Bağış T. Anxiety, depression and ways of coping skills by women with polycystic ovary syndrome: a controlled study. Journal of Turkish German Gynecological Association 2008; 9:190-194.

6. Ching HL, BurkeV, Stuckey BGA. Quality of life and psychological morbidity in women with polycystic ovary syndrome: body mass index, age and the provision of patient information are significant modifiers. Clin Endocrinol (Oxf) 2007; 66:373-379. 
7. Deeks AA, Gibson-Helm ME, Paul E, Teede HJ. Is having polycystic ovary syndrome a predictor of poor psychological function including anxiety and depression? Hum Reprod 2011; 26:1399-1407.

8. Cinar N, Kizilarslanoglu MC, Harmanci A, Aksoy DY, Bozdag G, Demir B, Yildiz BO. Depression, anxiety and cardiometabolic risk in polycystic ovary seyndrome. Hum Reprod 2011; 26:3339. 3345.

9. Rotterdam ESHRE / ASRM - sponsored PCOS Consensus Workshop Group Revised 2003 Consensus on diagnostic criteria and long term healty risks related to polycystic ovary syndrome. Fertil Steril 2004; 81:19-25.

10. Derogatis L. The Brief Symptom Inventory-BSI administration, scoring and procedures manual-II. Unpublished manuscript, 1992.

11. Derogatis L, Lazarus L. SCL 90-R Brief Symptom Inventory and Matching Clinical Rating Scales: In Maruish M (Editor). The Use of Psychological Testing for Treatment Planning and Outcome Assessment.Hillside, NJ: Lawrence Erlbaum Associates, 1994; 217-248.

12. Şahin NH, Durak A. Kısa Semptom Envanteri (Brief Symptom Inventory - BSI) Türk gençleri için uyarlanması. Türk Psikoloji Dergisi 1994; 31:44-56 (Article in Turkish).

13. Bem SI. The measurement of psychological androgyny. J Consult Clin Psychol 1974; 42:155-162.

14. Kavuncu N. Bem Cinsiyet Rolü Envanteri'nin Türk toplumuna uyarlama çalışması. Yüksek lisans tezi, Hacettepe Üniversitesi Sosyal Bilimler Enstitüsü, Ankara, 1987 (Article in Turkish).

15. Dökmen Z. BEM Cinsiyet Rolü Envanteri'nin geçerlilik ve güvenilirlik çalışması. Ankara Üniversitesi Dil ve Tarih Coğrafya Fakültesi Dergisi 1991; 35:81-89 (Article in Turkish).

16. Dokras A, Clifton S, Futterweit W, Wild R. Increased prevalence of anxiety symptoms in women with polycystic ovary syndrome: systematic review and meta-analysis. Fertil Steril 2012; 97:225230.

17. Barry JA, Kuczmierczyk AR, Hardiman PJ. Anxiety and depression in polycystic ovary syndrome: a systematic review and meta-analysis. Hum Reprod 2011; 26:2442-2451.

18. Livadas S, Chascout S, Kandaraki AA, Skourletos G, Economou F, Christou M, Boutzios G, Karachalios A, Zerva A, Xyrafis X, Christakau C, Pighou AK, Kandarakis ED. Anxiety is associated with hormonal and metabolic profile in women with polycystic ovarian syndrome. Clin Endocrinol 2011; 75:698-703.

19. Pastore LM, Patrie J, Morris WL, Dalal P, Bray MJ. Depression symptoms and body dissatisfaction association among polycystic ovary syndrome women. J Psychosom Res 2011; 71:270-276.
20. Benson S, Janssen OE, Hahn S, Tan S, Dietz T, Mann K, Pleger K, Schedlowski M, Arck PC, Elsenbruch S. Obesity, depression, and chronic low-grade inflammation in women with polycystic ovary syndrome. Brain Behav Immun 2008; 22:177-184.

21. Tarım Ö. Pediyatrik obeziteye genel bakış. Güncel Pediyatri Dergisi 2006; 4:28-31 (Article in Turkish).

22. Deveci A, Demet MM, Özmen B, Özmen E, Hekimsoy Z. Obez hastalarda psikopatoloji, aleksitimi ve benlik saygisı. Anadolu Psikiyatri Dergisi 2005; 6:84-91 (Article in Turkish).

23. Balcıŏlu İ, Başer SZ. Obezitenin psikiyatrikyönü. İ.Ü. Cerrahpaşa Tıp Fakültesi Sürekli Tıp Eğitimi Etkinlikleri Sempozyum Dizisi 2008; 62:341-348 (Article in Turkish).

24. Baysal B. Polikistik Over Sendromu ve Hirsutizm. İ.Ü. Cerrahpaşa Tıp Fakültesi Sürekli Tıp Eğitimi Etkinlikleri Sempozyum Dizisi 2008; 63:99-107 (Article in Turkish).

25. Jedel E, Gustafson D, Waern M, Sverrisdottir YB, Landen M, Janson PO, Labrie F, Ohlsson C, Victorin ES. Sex steroids, insulin sensitivity and sympathetic nerve activity in relation to affective symptomps in women with polycystic ovary syndrome. Psychoneuroendocrinology 2011; 36:1470-1479.

26. Kartalc1 Ş. Testosteron ve depresyon. Psikiyatride Güncel Yaklaşımlar 2010; 2:457-472 (Article in Turkish).

27. Kartalc1 Ş, Özsoy S, Ünal S, Eşel E. Depresyonlu kadın hastalarda testosteron ve $17-\mathrm{OH}$ progesteron düzeyleri ve antidepresan tedavinin etkisi. Anadolu Psikiyatri Dergisi 2010;11:285-292 (Article in Turkish)

28. Deeks AA, Gibson ME, Teede HJ. Anxiety and depression in polycystic ovary syndrome: a comprehensive investigation. Fertil Steril 2010; 93:2421-2423.

29. Benson S, Hahn S, Tan S, Mann K, Janssen OE, Schedlowski $\mathrm{M}$, Elsenbruch S. Prevalence and implications of anxiety in polycystic ovary syndrome: results of an internet-based survey in Germany. Hum Reprod 2009; 24:1446-1451.

30. Jedel E, Waern M, Gustafson D, Landen M, Eriksson E, Holm G, Nilsson L, Lind AK, Janson PO, Victorin ES. Anxiety and depression symtoms in women with polycystic ovary syndrome compared with controls matched for body mass index. Hum Reprod 2010; 25:450-456.

31. Mansson M, Holte J, Landin-Wilhelmsen K, Dahlgren E, Johansson A, Landen M. Women with polycystic ovary syndrome are often depressed or anxious-a case control study. Psychoneuroendocrinology 2008; 33:1132-1138.

32. Öztürk MO, Uluşahin A. (Editörler). Somatoform bozukluklar. Ruh sağlığı ve hastalıkları. Onbirinci baskı. Ankara, 2008, $537-$ 539 (Book in Turkish). 
33. Kesebir S, Aksoy AE. Üreme hormonlar1 ve duygudurum bozuklukları. Psikiyatride Güncel Yaklaşımlar 2010; 2:281-307 (Article in Turkish).

34. Baron-Cohen S, Lombardo MV, Augeung B, Ashwin E, Chakrabarti B, Knickmayer R. Why are autism conditions more prevalent in males? PLoS Biol 2011; 9:e1001081.
35. Knickmayer R, Baron-Cohen S, Fane BA, Wheelwright S, Mathews GA, Conway GS, Brook CGD, Hines M. Androgens and autistic traits: a study of individuals with congenital adrenal hyperplasia. Horm Behav 2006; 50:148-153. 